\title{
Developmental Regulation of Expression of C-Reactive Protein and Serum Amyloid A in Syrian Hamsters
}

\author{
S. BRUCE DOWTON, DARREL J. WAGGONER, AND KENNETH D. MANDL \\ Edward Mallinckrodt Department of Pediatrics and James S. McDonnell Department of Genetics, Washington \\ University School of Medicine, St. Louis, Missouri 63110 and the Harvard Medical School of Medicine, \\ Boston, Massachusetts 02115
}

\begin{abstract}
The fetal and maternal concentration of various plasma proteins alters during pregnancy. Cells in the livers of fetal hamsters accumulate serum amyloid $A$ (SAA) and C-reactive protein (CRP) mRNA, major acute phase reactants, when lipopolysaccharide is administered to the fetal circulation. No fetal SAA or CRP mRNA response is seen when the mother is stimulated at a remote site by endotoxin or a nonspecific inflammatory agent. In addition, cells of the fetal hamster liver do not respond by accumulating SAA mRNA when exposed to the specific cytokines, tumor necrosis factor, IL-1, and IL-6. CRP mRNA levels increased in fetal livers after administration of tumor necrosis factor and IL-1. These data suggest that cells contained in the fetal liver can respond during an acute phase reaction but that the capacity of some acute phase reactant genes to respond to cytokines may be developmentally regulated. Studies of immature hamsters after birth show that the responses of CRP and SAA genes to lipopolysaccharide, tumor necrosis factor, IL-1, and IL-6 are reduced when compared with induction of mRNA accumulation for these acute phase reactants in adult animals. (Pediatr Res 30: 444-449, 1991)
\end{abstract}

\section{Abbreviations}

CRP, C-reactive protein

SAA, serum amyloid A

LPS, lipopolysaccharide

TNF, tumor necrosis factor

After infection and tissue injury, homeostasis is restored by physiologic and metabolic alterations directed toward removal of the inciting agent and initiation of tissue repair. One component of the integrated host response to inflammation is alteration in concentrations of several plasma proteins-the acute phase reactants. During fetal and neonatal life, host defense mechanisms develop through a complex series of events and exposure to pathogenic microbes or other inflammatory stimuli during pregnancy and early life may cause cellular and humoral responses that differ from those observed in adult animals. Little information is available, however, regarding regulation of biosynthesis of major acute phase plasma proteins during develop-

Received March 19, 1991; accepted July 3, 1991

Correspondence and reprint requests: S. Bruce Dowton, M.D., Division of Medical Genetics, Department of Pediatrics, Washington University School of Medicine, 400 S. Kingshighway, St. Louis, MO 63110.

Supported by a grant from the National Institutes of Health (AI24835) and Basil O'Connor Starter Scholar Award (no. 5-669) from the March of Dimes Birth Defects Foundation. ment. The purposes of the studies detailed in this report were to determine the degree of inducibility of genes encoding two major acute phase plasma proteins during fetal and early life and to identify the mediators potentially responsible for such effects.

The magnitude of alteration in concentration of human acute phase plasma proteins is quite variable and interspecific differences have been recognized. The plasma concentration of some proteins, such as human $\mathrm{C} 3$ and ceruloplasmin may double during inflammation, whereas others including fibrinogen and $\alpha_{1}$-antiproteinase inhibitor may increase 5- to 20 -fold. However, the plasma concentration of SAA and CRP may increase by 100to 1000-fold after an inflammatory stimulus (1) as a result of enhanced transcription as well as altered posttranslational processing $(2,3)$. Because of the extent of increase in plasma concentration of SAA and CRP during inflammation, these proteins have been used for studies of regulation of expression of genes encoding acute phase reactants $(2,4)$.

Many consequences observed in the host during infection occur because of exposure to LPS, a major component of the outer membrane of Gram-negative bacteria (5). Administration of LPS causes a rapid increase in the concentration of several plasma proteins including SAA and CRP (6). After exposure to LPS, host macrophages or activated monocytes may elaborate cytokines including IL-1, TNF and IL-6, which in turn may alter the expression of genes encoding acute phase reactants (7). Accordingly, we have studied the expression of CRP and SAA mRNA in livers of fetal, maternal, and adult hamsters after administration of either nonspecific inflammatory stimuli or cytokines.

\section{MATERIALS AND METHODS}

Reagents. Escherichia coli LPS (serotype 0111:B4) was purchased from Sigma Chemical Co. (St. Louis, MO). Recombinant human IL-1, IL-6, and TNF were purchased from Amgen Inc. (Thousand Oaks, CA). Chemicals were obtained from Sigma Chemical Co., Fluka (Buchs, Switzerland), and Bethesda Research Laboratories (Gaithersburg, MD). Radiolabeled nucleotides were supplied by New England Nuclear (Buston, MA) and the nick translation kit was purchased from Boehringer-Mannheim (Indianapolis, IN).

Animals: fetal studies. Timed pregnant Syrian hamsters ( $M e$ socricetus auratus) were purchased from Charles River Laboratories (Wilmington, MA) or obtained from a colony maintained at Washington University Medical School.

For studies of expression of acute phase plasma protein genes during pregnancy, three experimental groups of multiparous hamsters were used and all were $13 \mathrm{~d}$ gravid (total pregnancy length $=17 \mathrm{~d}$ ). Each experiment in this section was duplicated unless otherwise indicated, and RNA samples were analyzed for expression of SAA and CRP. 
In the initial experiment, fetal and maternal RNA was isolated from livers, as detailed above, after maternal stimulation using s.c. turpentine $(0.5 \mathrm{~mL})$ to create a sterile abscess. An equivalent volume of sterile saline was given to control animals. Hamsters were killed 10 and $36 \mathrm{~h}$ after administration of turpentine, and maternal and fetal livers were immediately frozen in liquid nitrogen. Fetal livers from each mother were pooled.

In the second experimental group, pregnant hamsters were stimulated by intraperitoneal administration of LPS $(200 \mathrm{ng} / \mathrm{g})$ or cytokines (IL-1 $1.5 \mathrm{ng} / \mathrm{g}$, IL-6 $9 \mathrm{ng} / \mathrm{g}$, TNF $6 \mathrm{ng} / \mathrm{g}$ ). Maternal and fetal liver samples were harvested $10 \mathrm{~h}$ after dosage with the stimulating agent and immediately frozen in liquid nitrogen.

In the third experimental group, LPS or cytokines were administered into every placenta of three hamsters for each agent. For placental injections, $30 \mathrm{ng}(20 \mathrm{ng} / \mathrm{g}$ of individual fetus) LPS was prepared in $60 \mu \mathrm{L}$ pyrogen-free normal saline and injected into each placenta, which was easily visualized at laparotomy. Cytokines were similarly administered as follows: IL-1 $1.5 \mathrm{ng} / \mathrm{g}$, IL-6 $9 \mathrm{ng} / \mathrm{g}$, and TNF $10 \mathrm{ng} / \mathrm{g}$. Maternal and fetal liver samples were again harvested and frozen $10 \mathrm{~h}$ poststimulation.

Animals: postnatal studies. For analysis of acute phase plasma protein gene expression after birth, groups of hamsters (four per group) were injected intraperitoneally with either LPS, TNF, IL1 or IL- 6 . The CRP and SAA mRNA content of RNA samples was analyzed as described below. Animals were studied on d 1 , 10 , or 40 (adult) of life, and TNF and IL- 6 were given to separate sets (four per set) of immature hamsters at two different dosesthe lower dose being that which resulted in a discernible effect on SAA or CRP mRNA levels in adult animals. IL-1 was administered to animals on $\mathrm{d} 1$ and 10 at a dose $(1.5 \mathrm{ng} / \mathrm{g}$ body wt) that was twice the dose used for adult animals $(0.75 \mathrm{ng} / \mathrm{g}$ body wt). Livers were harvested $10 \mathrm{~h}$ after LPS or cytokine administration and handled as above. Control animals were given equivalent volumes of sterile normal saline by the same route.

RNA isolation and analysis. Hepatic RNA was isolated by pulverizing and lysing livers using $4.0 \mathrm{M}$ guanidinium isothiocyanate followed by ultracentrifugation of the guanidinium lysate on a $5.7 \mathrm{M}$ cesium chloride cushion in SW50.1 rotor tubes at $35000 \mathrm{rpm}$ for $18 \mathrm{~h}$ at $20^{\circ} \mathrm{C}(8)$. The pellet was washed in $70 \%$ ethanol, dissolved in water, and reprecipitated in ethanol with $0.3 \mathrm{M}$ sodium acetate at $-20^{\circ} \mathrm{C}$ overnight. The resulting precipitate was recovered by centrifugation $(13000 \mathrm{rpm}$ for $30 \mathrm{~min}$ at $4^{\circ} \mathrm{C}$ ) and solubilized in water.

For analysis, RNA samples $(10 \mu \mathrm{g})$ were fractionated by agarose-formaldehyde gel electrophoresis and transferred to nylon membranes by capillary transfer. After prehybridization overnight at $42^{\circ} \mathrm{C}$ in formamide $50 \%$, Denhardt's solution $5 \times$, SSPE $5 \times$, denatured salmon sperm DNA $50 \mu \mathrm{g} / \mathrm{mL}$, and dextran sulfate $5 \%$, blots were hybridized in the same solution with cDNA probes encoding hamster SAA or CRP. After washes at $65^{\circ} \mathrm{C}$ in $0.15 \mathrm{M}$ sodium chloride $/ 0.015 \mathrm{M}$ sodium citrate $/ 0.1 \%$ SDS, hybridizing signals were detected by autoradiography using Kodak XAR-5 film at $-70^{\circ} \mathrm{C}$. Signals were also analyzed by densitometry using a Beckman DU64 spectrophotometric densitometer as described (9). The statistical significance of changes in mRNA levels after administration of LPS or cytokines was assessed using an unpaired two-sided $t$ test of the densitometry data.

Uniformity of sample application to the gel was checked by visualization of ethidium bromide-stained RNA under UV light. In addition, blots were stripped and rehybridized with a crossreacting actin probe, $\mathrm{pAC} 269$, to examine the general effects of the turpentine, LPS, and cytokines on mRNA populations (10).

cDNA probes. A cDNA probe, phSAA1 (11), representing the entire coding sequence for one isotype of Syrian hamster SAA was used as one hybridization probe, and the CRP CDNA probe, phCRP1 (12), encodes the terminal 94 amino acids of hamster CRP and $1040 \mathrm{bp}$ of $3^{\prime}$ untranslated region. phSAA1 detects mRNA encoding all hamster SAA isotypes and both probes were radiolabeled with $\left[\alpha^{32} \mathrm{P}\right]$ deoxy cytidine triphosphate by nick translation to a sp act of $1 \times 10^{8} \mathrm{cpm} / \mu \mathrm{g}$.

\section{RESULTS}

Fetal SAA response to maternal inflammation or cytokines. After injection of turpentine to pregnant hamsters, a marked increase in hepatic SAA mRNA accumulation was documented in maternal samples, whereas no change of SAA mRNA levels was evident in fetal livers from the same animals (Fig. 1). Inflammation generated by turpentine injection has been previously shown to cause elevation of SAA mRNA levels in livers as well as other organs of adult hamsters within $12 \mathrm{~h}$ (11). Therefore, failure to detect fetal SAA mRNA at 12 or $30 \mathrm{~h}$ after onset of tissue injury in this experiment suggests that this is not simply due to a delay in placental signal transduction. Although SAA mRNA accumulated in livers of pregnant hamsters when LPS was provided by either intraperitoneal or transplacental injection, levels of SAA mRNA only increased in fetal livers when LPS was delivered by direct placental injection and not after intraperitoneal administration of LPS to the mother (Figs. 2 and 3). Elevations of maternal levels of hepatic SAA and CRP mRNA in control animals were observed after laparotomy for placental injections of saline (data not shown) and were presumably caused by surgical trauma.

In the experiment performed to examine the effect of cytokines on fetal acute phase gene expression during late gestation, SAA mRNA accumulated in maternal livers when IL-1, IL-6, and TNF were administered intraperitoneally (Fig. 2). However, using the same blot, expression of the hamster CRP gene was noted to be relatively high in pregnant control animals compared with nonpregnant animals and to increase slightly after LPS administration intraperitoneally. No change in CRP mRNA level was observed after TNF or IL-6 dosage, whereas IL-1 administration resulted in a decrease in CRP mRNA level (Fig. 2). Despite demonstrating the integrity of the RNA on this blot by subsequent hybridization with an actin probe, pAC269, and duplicating this result by repeating the blot with separate aliquots of the same RNA, these observations are inexplicable and are the subject of further study.

Maternal intraperitoneal administration of LPS or cytokines did not result in accumulation of SAA or CRP mRNA in fetal livers (Fig. 2), but transcripts for both of these acute phase reactants accumulate significantly $(p<0.01)$ when LPS is delivered via placental injection at laparotomy (Fig. 3). No accumulation of SAA mRNA was observed when cytokines were administered transplacentally (Fig. $3 A$ ) but TNF and IL-1 caused a significant $(p<0.05)$ elevation of CRP mRNA in fetal livers (Fig. 3B)

Postnatal response of $S A A$ and CRP to lipopolysaccharide. Administration of LPS to adult hamsters caused a rapid rise in hepatic levels of SAA and CRP mRNA confirming prior observations (Fig. 4) $(11,12)$. However, no significant difference was noted in mRNA levels for these acute phase reactants when an equivalent dose of LPS ( $100 \mathrm{ng} / \mathrm{g}$ body wt) was administered on the 1 st or 10th day of life. Furthermore, increasing the dose 5 -fold ( $500 \mathrm{ng} / \mathrm{g}$ body wt) did not result in a significant difference in level of SAA mRNA when compared with the saline-injected control animals on the 1st day of life, whereas CRP mRNA was elevated 3-fold above baseline. This difference is still less than the 25-fold difference in CRP mRNA seen between livers of adult hamsters when the lower dose was used (Fig. $4 B$ ) and fails to reach a level of statistical significance. Part of the difference is a result of the unexplained higher endogenous levels of CRP mRNA observed in immature animals where elevation of hepatic CRP mRNA levels was especially evident in control and stimulated animals at d 10. Levels of SAA mRNA after injection of LPS $(500 \mathrm{ng} / \mathrm{g})$ on the 10 th day of life were twice those for control animals, also not statistically significant, and less than the 10 -fold difference observed in adults after the smaller dose 


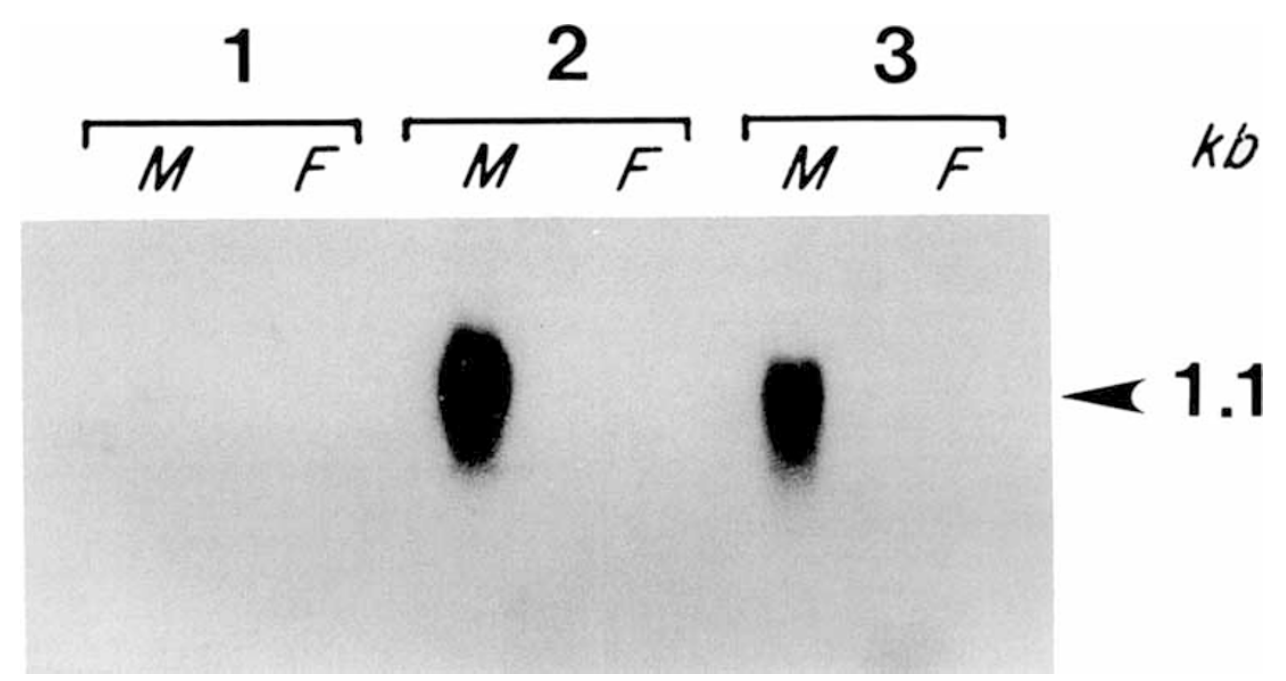

Fig. 1. RNA blot showing maternal and fetal expression of hamster SAA after induction of sterile abscess using turpentine. Maternal $(M)$ and fetal $(F)$ livers were harvested $10 \mathrm{~h}$ (lane 2) and $30 \mathrm{~h}$ (lane 3) after an s.c. injection of turpentine to the mother. The control animal (lane l) was given as s.c. sterile saline injection $(0.5 \mathrm{~mL})$.

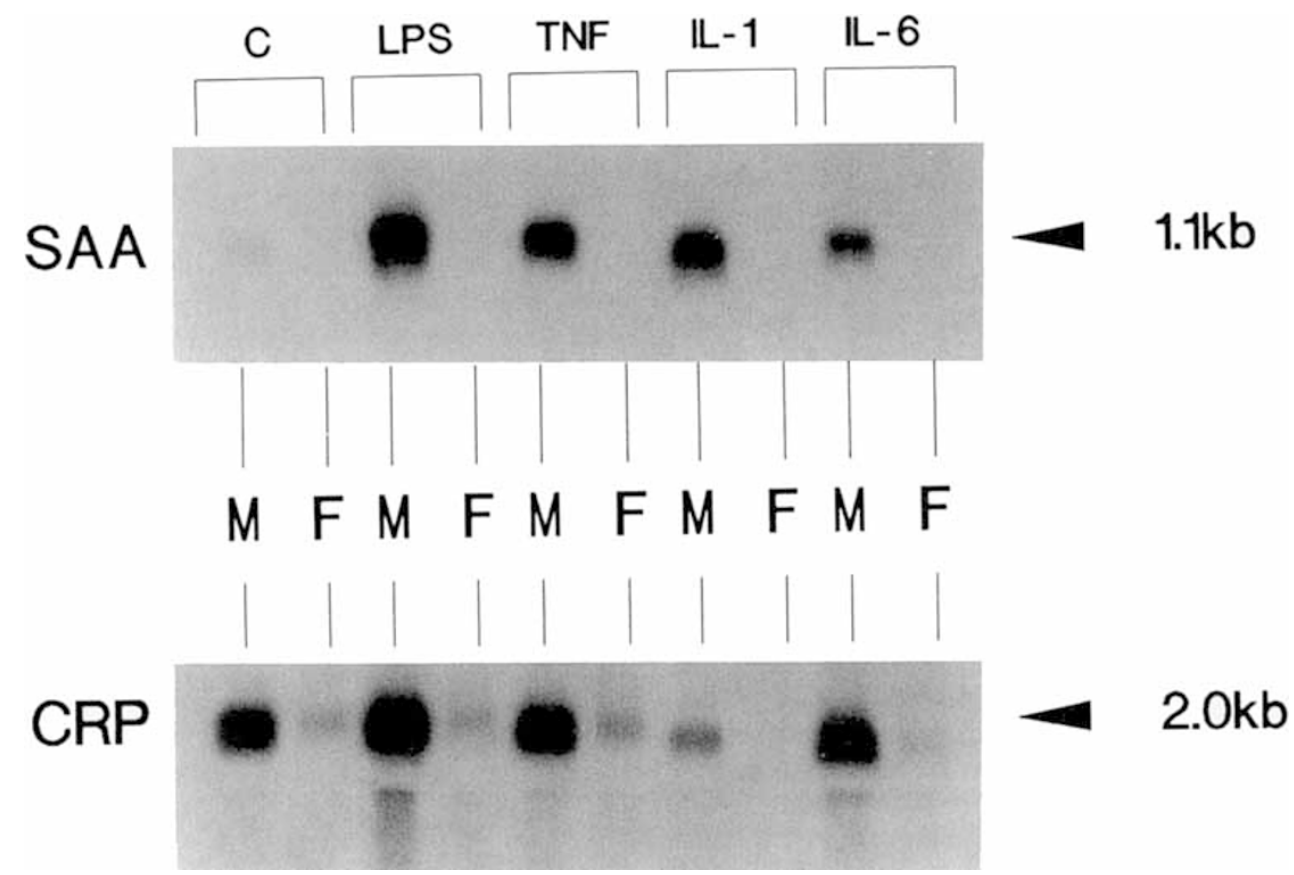

Fig. 2. Autoradiograph of RNA blot demonstrating maternal and fetal levels of SAA and CRP mRNA after intraperitoneal administration of LPS or cytokines to the mother. Maternal $(M)$ and fetal $(F)$ livers were harvested $10 \mathrm{~h}$ after administration of LPS (200 ng/g), TNF $6 \mathrm{ng} / \mathrm{g}, \mathrm{IL}-11.5$ $\mathrm{ng} / \mathrm{g}$, and IL-6 $9 \mathrm{ng} / \mathrm{g}$. Control animals received an equivalent volume of sterile saline. The blot was initially hybridized with SAA and after stripping rehybridized with CRP.

(Fig. $4 A$ ). In these experiments and the cytokine studies below, statistically significant alterations in actin mRNA levels were not observed within stimulated animals as compared with controls or between ages (data not shown).

Postnatal response of $S A A$ and CRP to cytokines. Results similar to those observed after LPS administration were noted when 1-d-old, 10-d-old, and adult hamsters were administered purified cytokines. Again, SAA and CRP mRNA levels increased in livers of adult animals after exposure of animals to recombinant IL-6 (Fig. 5), TNF (Fig. 6), and IL-1 (Fig. 7), but no significant difference was noted in mRNA levels for these acute phase reactants in immature animals. Adult differences in levels of SAA and CRP mRNA between control and cytokine-treated animals are all statistically significant at $p<0.001$. Escalation of cytokine dosages, by 3 - to 5 -fold, failed to induce significant change in acute phase protein mRNA levels. Within each cyto- kine study group, animals at all ages were injected and samples were processed concurrently to ensure consistency of the cytokine action. The rather striking elevation of baseline hepatic CRP and SAA mRNA levels in 10-d-old animals for animals receiving IL-6 and TNF, respectively, remains unexplained. However, because the experiments for animals given each mediator were separated by some time, valid comparisons between the groups may not be possible.

\section{DISCUSSION}

Maternal, fetal, and neonatal concentrations of various plasma proteins alter in pregnancy and the postpartum period. Such changes in levels of acute phase plasma proteins may be important in controlling proteolytic processes occurring during pregnancy, parturition, and early growth. For example, levels of $\alpha_{2}$ - 

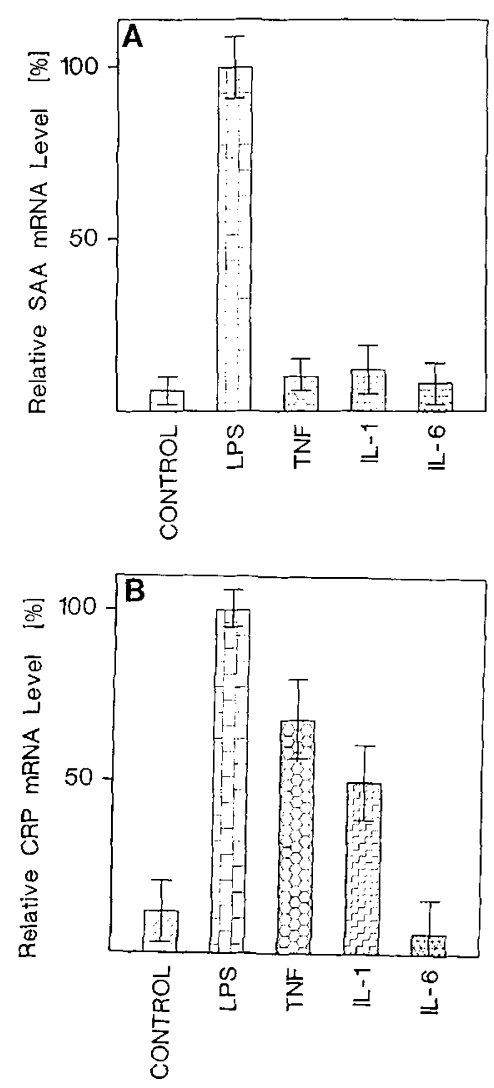

Fig. 3. Levels of SAA $(A)$ and CRP $(B)$ mRNA in fetal livers after direct placental administration of LPS or cytokines. Fetal hamster livers were harvested $10 \mathrm{~h}$ after administration of LPS $(20 \mathrm{ng} / \mathrm{g})$, TNF $(10 \mathrm{ng} /$ g), IL-1 $(1.5 \mathrm{ng} / \mathrm{g})$, or IL-6 $(9 \mathrm{ng} / \mathrm{g})$ by placental injection at laparotomy. Results are displayed as a percentage of maximal RNA level (LPS). Densitometrically determined RNA levels are displayed as a percentage of the maximal signal (LPS-treated animals), which was arbitrarily designated as $100 \%$. Error bars represent 1 SEM, and statistical significance is achieved for elevations of CRP mRNA after LPS $(p<0.01)$, TNF, and IL-1 $(p<0.05)$.

macroglobulin, which is a multifunctional plasma proteinase inhibitor, increase dramatically in rats shortly before birth (13). Liver-derived plasma proteins are synthesized at differing stages of embryogenesis, and an acute phase reaction for some of these proteins has been demonstrated in neonatal animals, although clear differences from responses observed in mature animals have been noted (14). These observations have been extended to clinical utility in some circumstances, e.g. quantitation of CRP as a marker for chorioamnionitis (15). CRP is a cyclic pentamer that has a number of functions including interaction with phagocytic cells, the complement cascade, lymphocytes, platelet activation, and perhaps clearance of chromatin released from nuclei of necrotic cells (16-19). Like CRP, SAA is a major acute phase protein and has been used in regulatory studies of gene expression during inflammation. The plasma concentration of $\mathrm{SAA}$, a $12-\mathrm{kD}$ protein having the potential to form amyloid (20, 21 ), is very low in most species and its function remains largely unknown. Influences of SAA in cellular activation and rapid clearance of HDL particles, to which SAA adheres, have been proposed as possible functions (22).

The results of this study suggest that the expression of genes encoding these two major acute phase plasma proteins may be developmentally regulated. These data demonstrate that cells of fetal hamster livers respond to LPS by enhanced SAA and CRP mRNA production during late gestation only when the LPS gains direct access to the fetal circulation. Previous studies demonstrate that other stimulatory properties of LPS, such as induction of cyclic GMP levels and TNF- $\alpha$ activity, are also present
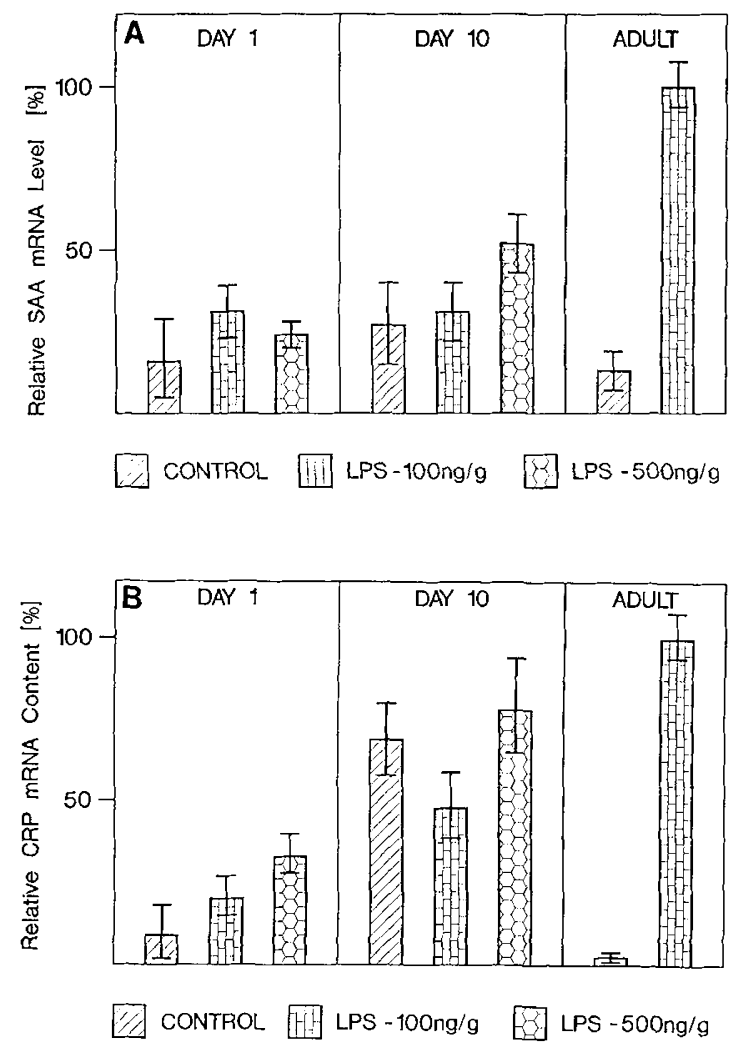

Fig. 4. Levels of SAA $(A)$ and CRP $(B)$ mRNA after LPS. Doses ( 100 $\mathrm{ng} / \mathrm{g}$ body wt and $500 \mathrm{ng} / \mathrm{g}$ body wt) given to animals on $\mathrm{d} 1,10$, and 40 (adult) are indicated by hatching. Densitometrically determined RNA levels are displayed as a percentage of the maximal signal (stimulated adult), which was arbitratily designated as 100\%. Error bars represent 1 SEM.

in livers of immature animals $(23,24)$. The observation that none of the exogenously administered cytokines induced fetal SAA mRNA accumulation perhaps indicates that the LPS response upon direct placental injection is due to induction of another mediator capable of transducing the signal in either fetal or placental tissues. Alternatively endotoxin may be acting directly upon fetal cells to stimulate transcription of the SAA genes. Turpentine has also been used as a stimulant of the acute phase plasma protein response, and elevation of fetal levels of several proteins including $\alpha_{2}$-macroglobulin, haptoglobin, $\alpha_{1}$-acid glycoprotein, and hemopexin has been noted in fetal rats although the magnitude of increase is markedly less than in adult animals (25). However, in neonatal hamsters SAA or CRP mRNA did not significantly accumulate after LPS administration, and the normal adult responsiveness to this stimulus is not present by d 10 of life. Expression of acute phase plasma protein genes in vivo is a multi-step process, and the current data may imply activity of a maternally or placentally derived component in permitting acute phase plasma protein gene expression in fetuses that has not yet developed in immature animals. Because direct administration of three cytokines into the placenta failed to elicit an SAA mRNA response, it seems less likely that the LPS effect is caused by elaboration of any of these cytokines from a site of placental injection as a result of the injection.

From our studies, the cellular origin of fetal SAA synthesis is not evident. Other investigators have reported that SAA is produced by macrophages at extrahepatic sites, and determination of whether hepatocytes or Kupffer cells are responsible for fetal SAA production in these experiments will be resolved by in situ hybridization (26). SAA3 is the isotype that is produced by macrophages, and availability of nucleotide sequence data for SAA1, SAA2, and SAA3 in hamsters will permit analyses of 


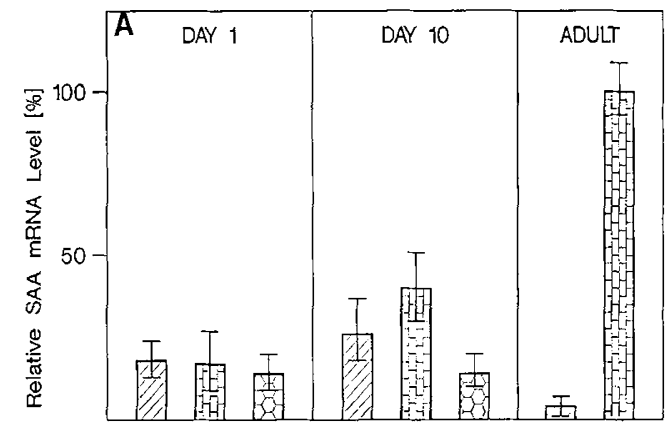

CONTROL

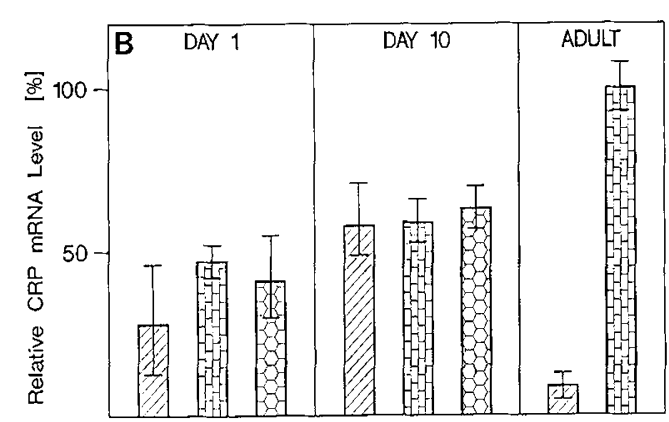

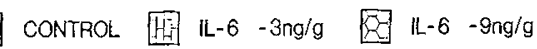

Fig. 5. Levels of SAA $(A)$ and CRP $(B)$ mRNA after IL-6. Two doses ( $3 \mathrm{ng} / \mathrm{g}$ body wt and $9 \mathrm{ng} / \mathrm{g}$ body $\mathrm{wt}$ ) were used for immature animals (1 and $10 \mathrm{~d}$ old), and adult animals received the lower dose ( $3 \mathrm{ng} / \mathrm{g}$ body $w t)$. Densitometrically determined RNA levels are displayed as a percentage of the maximal signal (stimulated adult), which was arbitrarily designated as $100 \%$. Error bars represent 1 SEM.

tissue specific of the expression of these genes during development (11).

A fetal SAA acute phase response was not documented when maternal inflammation was stimulated at a remote site by either s.c. turpentine or intraperitoneal LPS. The times of exposure of fetuses to agents inducing an acute phase response were selected to encompass a range during which an increase in hepatic SAA mRNA level would be expected (11). Therefore, it is unlikely that failure of the fetal liver to respond in experiments of remote stimulation is due to insufficient time of exposure. The dose of LPS administered to the mothers intraperitoneally, which did not result in a fetal response, was well in excess of that injected into the placental circulation after which SAA mRNA accumulation was noted. These data suggest that the absence of a fetal SAA mRNA response after remote LPS stimulation to the mother is probably not due to insufficient dosage of the endotoxin. In perinatal life, administration of LPS in a dose equivalent to that which causes an acute phase response in adults failed to provoke accumulation of mRNA not only for SAA but also for CRP, suggesting that a more generalized phenomenon may be operative. Many of the effects of LPS are coordinated by cytokines including IL-1, IL-6, and TNF. Availability of homogeneous preparations of these mediators has permitted detailed studies of their involvement in host responses to inflammation (27). TNF shares several functional activities with $\mathrm{IL}-1$ including signal transduction during acute inflammation (28). This cytokine has reversible time- and dose-dependent effects on synthesis of several acute phase plasma proteins in human hepatoma cell lines (27). TNF activity has been detected in fetal cells and, although secretion of TNF is enhanced by LPS $(29,30)$, there may be quantitative differences in the magnitude of endotoxic TNF response during fetal life $(31,32)$. Absence of a fetal SAA mRNA response to each of the cytokines tested suggests that
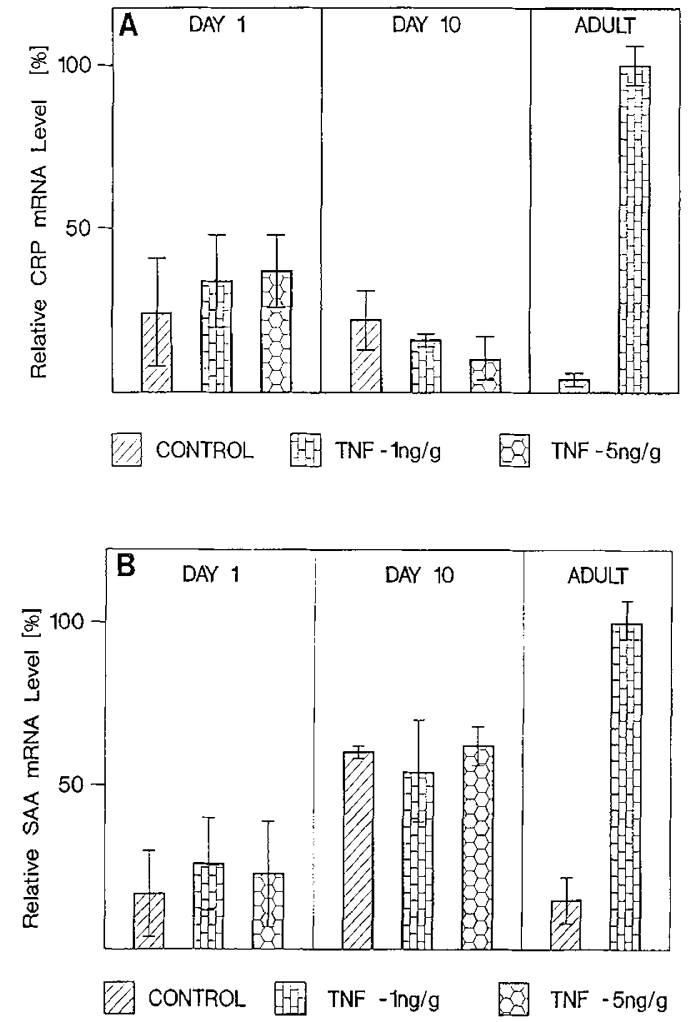

Fig. 6. Levels of SAA $(A)$ and CRP $(B)$ mRNA after TNF. Two doses ( $1 \mathrm{ng} / \mathrm{g}$ body wt and $5 \mathrm{ng} / \mathrm{g}$ body wt) were used for immature animals (1 and $10 \mathrm{~d}$ old $)$, and adult animals received the lower dose ( $1 \mathrm{ng} / \mathrm{g}$ body wt). Densitometrically determined RNA levels are displayed as a percentage of the maximal signal (stimulated adult), which was arbitrarily designated as $100 \%$. Error bars represent 1 SEM.

inducibility of the SAA gene family may indeed be developmentally regulated. An equivalent dose for maternal intraperitoneal injections and fetal transplacental injections was used, which suggests again that failure of SAA mRNA accumulation in each case is not due to inadequate dosage. The lack of elevation of SAA mRNA levels in fetal hamsters in response to cytokines persists after birth.

Although CRP mRNA accumulated after placental administration of TNF, transcript levels of this acute phase reactant did not alter in response to TNF at 1 and $10 \mathrm{~d}$ of life. The action of TNF is mediated by a specific cell-surface receptor (33), and these data may imply failure of neonatal expression of other trans-acting factors or components of the signal transduction pathway that may be derived from the maternal circulation or placenta in fetal life.

Similar results to those noted for TNF with respect to induction of SAA and CRP mRNA were observed when 1- and 10-dold hamsters were given IL-1 or IL-6. IL- 6 is produced by several cell types and is a potent stimulus to SAA and CRP production in cell lines and in studies of promoters for these acute phase genes linked to reporter genes $(34,35)$. Production of IL-6 has been documented in fetal and neonatal mononuclear cells ( 36 37) and, although differences in action of IL-6 upon fetal hematopoietic progenitors compared with adult blood precursors have been described (38), the mechanism of such developmental differences remains to be elucidated. Data in this report suggest an immaturity of the mechanism involved in stimulation of CRP and SAA biosynthesis by IL- 6 as well as IL-1 and TNF in young hamsters.

The study presented here provides information concerning the capacity of immature animals to develop an acute phase reaction with respect to two major acute phase plasma proteins. SAA and CRP induction occurs in fetal hamster livers when LPS is deliv- 


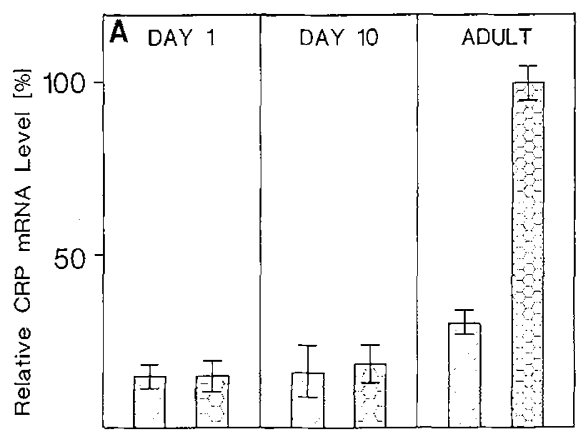

CONTROL $\quad \mathrm{IL}-1$

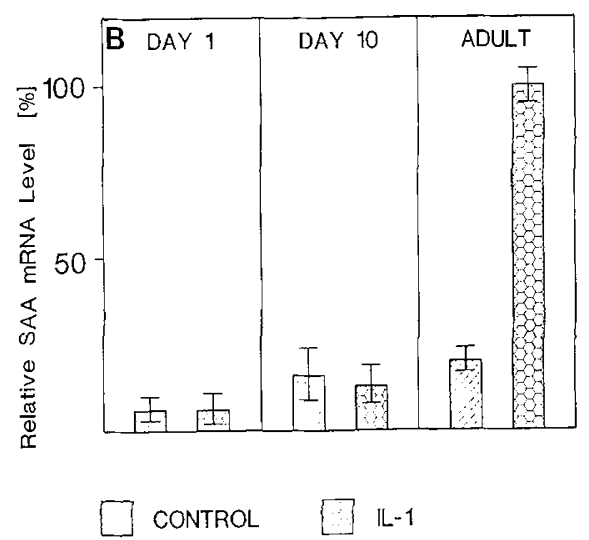

Fig. 7. Levels of SAA $(A)$ and CRP $(B)$ mRNA after IL-1. IL-1 was administered $(1.5 \mathrm{ng} / \mathrm{g}$ body $\mathrm{wt}$ ) to immature animals ( 1 and $10 \mathrm{~d}$ old). Adult animals received $0.75 \mathrm{ng} / \mathrm{g}$ body wt. Densitometrically determined RNA levels are displayed as a percentage of the maximal signal (stimulated adult), which was arbitrarily designated as $100 \%$. Error bars represent 1 SEM.

ered directly to the placenta. Remote stimulation of the mother does not cause SAA and CRP mRNA accumulation. Although the mediator of enhanced SAA biosynthesis in fetal life after LPS exposure has not been identified, IL-1, IL-6, and TNF have been excluded. CRP transcripts accumulate after placental administration of TNF, but this response and the effects of LPS upon expression of this gene as well as sequences encoding SAA are abolished in neonates. Further studies are needed to 1) identify the cell type that synthesizes CRP and SAA in fetal life; 2) define the inducibility of genes encoding these proteins at earlier gestational stages; and 3) understand the components in the signal transduction pathway that are responsible for the developmental differences in the acute phase response.

Acknowledgments. The authors thank Harvey R. Colten for his helpful suggestions and Scott D. McGrew for his excellent technical assistance.

\section{REFERENCES}

1. Kushner I 1982 The phenomenon of the acute phase response. Ann NY Acad Sci 389.39-48

2. Goldberger G, Bing DH, Sipe JD, Rits M, Colten HR 1987 Transcriptional regulation of genes encoding the acute-phase proteins CRP, SAA and C3. J Immunol 138:3967-3971

3. MacIntyre SS, Kushner I, Samols D 1985 Secretion of C-reactive protein becomes more efficient during the course of the acute phase response. $J$ Biol Chem 260:4169-4173

4. Lowell CA, Stearman RS, Morrow JF 1986 Transcriptional regulation of serum amyloid A gene expression. J Biol Chem 261:8453-8461

5. Morrison DC 1983 Bacterial endotoxins and pathogenesis. Rev Infect Dis 5(suppl 4):S733
6. Sipe JD 1978 Induction of acute-phase serum protein SAA requires both RNA and protein synthesis. Br J Exp Pathol 59:305

7. Fey GH, Fuller GM 1987 Regulation of acute phase gene expression by inflammatory mediators. Mol Biol Med 4:323-338

8. Sambrook J, Fritsch EF, Maniatis T 1989 Molecular Cloning. A Laboratory Manual, 2nd ed. Cold Spring Harbor Laboratory Press, Cold Spring Harbor

9. Dowton SB, McGrew SD 1990 Rat serum amyloid P component: analysis of CDNA sequence and gene expression. Biochem J 270:553-556

10. Schwartz RJ, Haron JA, Rothblum KN, Dugaiczyk A 1980 Regulation of muscle differentiation: cloning of sequences from a-actin messenger ribonucleic acid. Biochemistry 79:5883-5890

11. Webb CF, Tucker PW, Dowton SB 1989 Expression and sequence analyses of serum amyloid $A$ in the Syrian hamster. Biochemistry 28:4785-4790

12. Dowton SB, Holden SN 1991 C-reactive protein (CRP) of the Syrian hamster. Biochemistry (in press)

13. Panrucker DE, Lai PCW, Lorscheider FL 1983 Distribution of acute-phase $\alpha_{2}$-macroglobulin in rat fetomaternal compartments. Am J Physiol 245:138 142

14. Fletcher S, Thomas T, Schreiber G, Heinrich PC, Yeoh GC 1988 The development of rat alpha 2-macroglobulin. Studies in vivo cultured fetal rat hepatocytes. Eur J Biochem 171:703-709

15. Hawrylyshyn P, Bernstein P, Milligan JE, Soldin S, Pollard A, Chir B, Papsin FR 1983 Premature rupture of membranes: the role of $C$-reactive protein in the prediction of chorioamnionitis. Am J Obstet Gynecol 147:240-246

16. Siegel J, Osmand AP, Wilson MF, Gewurz H 1975 Interactions of C-reactive protein with the complement system. Il. C-reactive protein-mediated consumption of complement by poly-L-lysine polymers and other polycations. J Exp Med 142:709-721

17. Fiedel BA, Simpson RM, Gewurz H 1982 Activation of platelets by modified C-reactive protein. Immunology 45:439-447

18. Pepys MB, Butler PJ 1987 Serum amyloid P component is the major calciumdependent specific DNA binding protein of the serum. Biochem Biophys Res Commun 148:308-313

19. James K, Hansen B, Gewurz H 1981 Binding of C-reactive protein to human lymphocytes. J Immunol 127:2539-2544

20. Linke RP, Sipe JD, Pollock PS, Ignaczak TF, Glenner GG 1975 Isolation of a low-molecular-weight serum component antigenically related to an amyloid fibril protein of unknown origin. Proc Natl Acad Sci USA 72:1473-1476

21. Benditt EP, Eriksen N 1977 Amyloid protein SAA is associated with high density lipoprotein from human serum. Proc Natl Acad Sci USA 74:40254028

22. Benditt EP, Meek RL, Eriksen N 1989 ApoSAA: structure, tissue expression and possible functions. In: Pepys MB (ed.) Acute Phase Proteins in the Acute Phase Response. Springer-Verlag, London, p 59-67

23. Graber SE, Hellerqvist CG 1982 Direct evidence that bacterial lipopolysaccharides elevate cycle GMP levels in rat fetal liver cells. J Biol Chem 257:5414

24. Adams JL, Semrad SD, Czuprynski CJ 1990 Administration of bacterial lipopolysaccharide elicits tumor necrosis factor-alpha in neonatal calves. $J$ Clin Microbiol 28:998-1001

25. Vranckx R, Savu L, Cohen A, Maya M, Nunez E 1989 Inflammatory competence of fetal rat: acute-phase plasma protein response of the fetus treated by turpentine in utero. Inflammation 13:79-90

26. Meek RL, Benditt EP 1986 Amyloid A gene family expression in different mouse tissues. J Exp Med 164:2006-2017

27. Perlmutter DH, Dinarello CA, Punsal PI, Colten HR 1986 Cachectin/tumor necrosis factor regulates hepatic acute-phase gene expression. $\mathrm{J}$ Clin invest 78:1349

28. Beutler B, Cerami A 1987 Cachectin: more than a tumor necrosis factor. $N$ Engl J Med 316:379

29. Yamasu K, Onoe H, Soma G, Oshima H, Mizuno D 1989 Secretion of tumor necrosis factor during fetal and neonatal developmental of the mouse: ontogenic inflammation. J Biol Response Mod 8:644-655

30. Silen ML, Hesse DG, Felsen D, Moldawer LL, Calvano SE, Seniuk S, Cerami A, Lowry SF 1989 Cachectin/tumor necrosis factor production by fetal and newborn hepatic macrophages. J Pediatr Surg 24:34-38

31. Weatherstone KB, Rich EA 1989 Tumor necrosis factor/cachectin and interleukin-1 secretion by blood monocytes from premature and term neonates. Pediatr Res 25:342-346

32. English BK, Burchett SK, English JD, Ammann AJ, Wara DW, Wilson CB 1988 Production of lymphotoxin and tumor necrosis factor by human neonatal mononuclear cells. Pediatr Res 24:717-722

33. Hohmann H-S, Remy R, Brockhaus M, van Loon APGM 1989 Two different cell types have different major receptors for human tumor necrosis factor (TNF $\alpha$ ). J Biol Chem 264:14927-14934

34. Heinrich PC, Castell JV, Andus T 1990 Interleukin- 6 and the acute phase response. Biochem J 265:621-636

35. Ciliberto, $G 1989$ Transcriptional regulation of acute phase response genes with emphasis on the human C-reactive gene. In: Pepys MB (ed) Acute Phase Proteins in the Acute Phase Response. Springer-Verlag, London, p 29-46

36. Yachic A, Takano N, Yokoi T, Kato K, Kasahara Y. Taniguchi N 1990 The capability of neonatal leukocytes to produce IL- 6 on assessed by whole blood culture. Pediatr Res 27:227-233

37. Matsuzaki N, Saji F, Kameda T, Yoshizaki K, Okada T. Tanizawa O 1990 In vitro and in vivo production of interleukin-6 by fetal cells. Clin Immunol Immunopathol 55:305-314

38. Gardner JD, Liechty KW, Christensen RD 1990 Effects of interleukin-6 on fetal hematopoietic progenitors. Blood 75:2150-2155 